\title{
ВИКОРИСТАННЯ РІЗНИХ СПОСОБІВ РОЗМНОЖЕННЯ БЕРЕКИ ЛІКАРСЬКОЇ ЗА ВІДНОВЛЕННЯ У СВІЖИХ ДІБРОВАХ ПІВДЕННО-ПОДІЛЬСЬКОГО ЛІСОСТЕПУ УКРАЇНИ
}

\begin{abstract}
Відтворення лісових насаджень за участю цінних видів деревних порід на сучасному етапі розвитку суспільства $є$ актуальним завданням лісового господарства. Берека лікарська (Sorbus torminalis (L.) Crantz) - аборигенний вид, занесений до Червоної книги України (2009). Природний супутник лісових ценозів Південно-Подільського Лісостепу України, поновлення якого досліджували протягом п'яти років у деревостанах усіх вікових категорій та на зрубах, де залишені репродуктивні особини виду. Для дослідження кількісних та якісних показників поновлення Sorbus torminalis закладено 60 тимчасових та 11 постійних пробних площ. Природне насіннєве розмноження Sorbus torminalis виявлено у свіжих дібровах Південного Поділля. Насіння зберігає життєздатність 1-2 роки. У природних дубово-грабових насадженнях плодоношення настає в 20-річному віці, масове плодоношення спостережено раз у 5 років. Насіннєве розмноження використано для отримання сіянців $\mathrm{i}$ саджанців з метою введення Sorbus torminalis у культури дуба звичайного. Кращі результати отримано завдяки осіннім висівам свіжовимитого насіння за умов дотримання відповідних технологій. Осінні висіви здійснено у другій декаді вересня. Такі висіви дають весною дружні сходи і рівень їх грунтової схожості знаходиться в межах 78 \%, що є досить успішним результатом для виду. Вегетативне порослеве розмноження сприяє ії відновленню у разі механічних пошкоджень. Вирішення проблеми розмноження та оздоровлення породи можливе за умови використання сучасних досягнень біотехнології, одним 3 яких $є$ метод мікроклонального розмноження. Цей метод дає можливість у стислі терміни одержати масовий, генетично однорідний садивний матеріал 3 високими спадковими властивостями продуктивності та стійкості до збудників хвороб. Для введення в культуру in vitro були верхівкові бруньки, нарізані з однорічних пагонів маточних рослин. Підібрано стерилізатори, а також визначено відповідні концентрації поживного середовища та експозиції. Впровадження різних способів розмноження береки лікарської сприятиме відновленню насаджень з ії участю, а також розширення ареалу виду, що зникає.
\end{abstract}

Ключові слова: Sorbus torminalis; статеве розмноження; вегетативне розмноження; мікроклональне розмноження.

Вступ. Лісові ресурси є самовідновними, але з посиленням антропогенного впливу на природні екосистеми, зважаючи на інтенсивне їх використання, вони потребують сприяння відновленню. Відтворення лісових насаджень за участю цінних видів деревних порід на сучасному етапі розвитку суспільства $\epsilon$ актуальним завданням лісового господарства. Одними 3 таких видів $\epsilon$ представник родини Розові (Rosaceae) - берека лікарська (Sorbus torminalis (L.) Crantz). Природоохоронний статус $S$. torminalis зумовлює необхідність розробки методів розмноження для збереження цього виду (Termena \& Budzhak, 1997; Didukh, 2009).

Берека лікарська - природний супутник лісових ценозів Південно- Подільського Лісостепу України. Вид є надзвичайно цінним компонентом українських лісів, росте в суміші 3 дубом, буком, ясенем, грабом, бере участь у формуванні другого ярусу деревостанів. Природне насіннєве поновлення ііі у природі відбувається стихійно (Kushnir \& Sarnatska, 2005; Litopys, 2018). Проте ця стихійність має свої закономірності, які потрібно враховувати, вивчати і використовувати в лісовому господарстві (Pohrebniak, 1993). Для того, щоб берека цілком не зникла 3 наших лісів, проводили моніто- ринг за станом популяції та дослідження ареалу поширення береки.

Мета дослідження - проаналізувати вплив змін просторової структури насадження на можливість використання різних способів розмноження береки лікарської в умовах Південно-Подільського Лісостепу України.

Матеріали та методи дослідження. Дослідження проводили в умовах свіжої дубово-грабової діброви у Бритавському, Червоногребельському, Дохнянському лісництвах державного підприємства "Чечельницьке лісове господарство". Деревостан, в яких проводили дослідження, має складну триярусну структуру 3 дубом звичайним та скельним, ясенем звичайним у першому ярусі. Другий ярус представлений грабом звичайним, липою дрібнолистою, кленом гостролистим та польовим, берекою лікарською, берестом (Tsymbal, 2011; Shpak, 2016, 2018, 2019). У підліску ростуть переважно бруслина європейська та бородавчаста, глід п'ятистовпчиковий та колючий, калина гордовина, дерен справжній, свидина біла.

Об'єкт дослідження - процеси відновлення та способи розмноження береки лікарської. Берека лікарсь-

\section{Інформація про авторів:}

Шпак Ніна Петрівна, науковий співробітник, відділ науки. Email: spaknina0@gmail.com

Цитування за ДСтУ: Шпак Н. П. Використання різних способів розмноження береки лікарської за відновлення у свіжих дібровах Південно-Подільського Лісостепу України. Науковий вісник НЛтУ України. 2019, т. 29, № 7. С. 17-20.

Citation APA: Shpak, N. P. (2019). The use of Different Methods of Reproduction of Sorbus torminalis (L.) Crantz for Renewal in Fresh Oak Forests of South Podillya Forest-Steppe of Ukraine. Scientific Bulletin of UNFU, 29(7), 17-20.

https://doi.org/10.15421/40290703 
ка - аборигенний вид, занесений до Червоної книги України (2009), об'єкт природної популяції Південного Поділля, поновлення якого досліджували протягом п'яти років у деревостанах усіх вікових категорій та на зрубах, де залишені репродуктивні особини виду.

Основними методами дослідження були аналіз, синтез і порівняння різних способів розмноження береки лікарської, які сприятимуть відновленню виду в природних і штучних насадженнях. Для дослідження кількісних та якісних показників поновлення береки лікарської заклали 60 тимчасових та 11 постійних пробних площ згідно з методичними рекомендаціями під редакцією проф. С. С. П'ятницького та рекомендаціями УкрНДІЛГА (Piatnitckii, 1994). Для вивчення лісопоновлювальних процесів насамперед встановлювали кількість підросту, ступінь його життєздатності під наметом деревостану різної зімкнутості в найпоширеніших умовах лісу. Облік поновлення під наметом лісу та на зрубах проводили, використовуючи методики С. С. П'ятницького, М. М. Горшеніна (Gorshenin \& Shvidenko, 1977), згідно з якими на пробній площі рівномірно закладали облікові площадки $10 \mathrm{~m}^{2}$ (за середньої густоти підросту) і $20 \mathrm{~m}^{2}$ (за рідкого підросту), на яких щорічно визначали видовий склад підросту, його кількість і вік. На підставі отриманих даних оцінювали успішність насіннєвого розмноження береки лікарської. Біологічною особливістю виду під час природного поновлення є здатність зберігати тривалий час життєвість за недостачі освітлення, але після п'ятирічного віку самосів випадає, якщо в підрості переважає граб або ясен, а в культурах - високий трав'яний покрив.

Результати дослідження. За результатами дослідження встановили, що відновлення береки лікарської в насадженнях відбувається природним, штучним і комбінованим шляхами. Природне поновлення: насіннєве i вегетативне. Під час природного насіннєвого поновлення враховували: плодоношення, поширення насіння, кількість, ріст і розвиток сіянців та підросту. Встановили, що берека масово плодоносить у віці 25-40 років. Перше плодоношення в лісових масивах настає після 20 років, а у 60-70-річному віці спостерігаємо незначне плодоношення в окремі роки. Берека лікарська відзначається інтенсивним щорічним цвітінням (4-5 балів за шкалою В. Г. Каппера), а плодоношення низьке (1-2 бали). Висока врожайність буває раз у п'ять років, у наступний рік плодоношення повністю відсутнє. Енергетичний запас відновлюється на 2-3 рік. Самосів береки в проекції крон трапляється дуже рідко, переважно на узліссі і в лісосмугах. Самосів $є$ на освітлених ділянках лісу за межами крони на віддалі 100-150 м по 3-4 сіянці на м $^{2}$. Птахи сприяють поширенню насіння, самосів часто трапляється у насадженнях за відсутності плодоносних дерев та на лучно-степових ділянках, які прилягають до лісових масивів. Природне насіннєве поновлення виду дуже слабке, що також залежить від кількості вологи в осінній та весняний періоди. За шкалою оцінки природного насіннєвого відновлення М. М. Горшеніна, берека має незадовільну категорію.

Другим способом розмноження береки лікарської можна вважати порослеве. Вона добре відновлюється після пошкоджень молодих пагонів тваринами або після освітлення та прорідження культур дуба. Пенькова поросль дає 3-4 рівноцінних пагонів, які швидко ростуть (за вегетаційний період приріст становить 25-
36 см). 3 роками вони не пригнічують один одного. Корені поширюються поверх материнського коріння, довжина яких досягає до 3 м (кв. 36/11, вік 15 років, Дохнянське лісництво).

Статеве розмноження не завжди реалізується зокрема на біологічні особливості будови насіння та несприятливі кліматичні умови: весняна і літня посухи спричиняють висихання плодів. Тому рекомендували спосіб відновлення береки лікарської в дібровах Поділля, тобто введення ії в культури дуба звичайного як супутню породу. Особливість вирощування сіянців береки розглянуто в літературних джерелах, проте багато з них подають різні дані, що утруднює вирощування садивного матеріалу. Окремі дослідники, наголошують, що посіви береки восени $є$ переважно невдалими і тї насіння необхідно обов'язково стратифікувати (Termena \& Budzhak, 1997). На думку А. О. Бондара та М. I. Гордієнка (Bondar \& Hordiienko, 2006; Hordiienko, Koretskyi \& Maurer, 1995), насіння береки необхідно стратифікувати протягом 3-4 місяців у підвальних приміщеннях із постійною температурою повітря і високою його вологістю. Досліджували стратифікацію насіння впродовж трьох років i отримували різні результати, а саме: в 2015 р. насіння проросло через 3 місяці, а в 2017 р. - через 2 (в лютому), в 2016 - $72 \%$ не вийшло з стану спокою. Ми вибрали надійніший спосіб отримання сіянців і саджанців- це висів свіжовимитого насіння на 2-3 день після збору плодів. Брали норму висіву 2 г на погонний метр, глибина загортання насіння 3-5 см. Якщо проводити сівбу пересохлим насінням, яке через 5-6 днів після видобування 3 плоду досить сильно висихає, то навесні з'являються тільки поодинокі сходи (Shpak, Shlapak \& Leontiak, 2017). Осінній висів показав високу грунтову схожість $67,1 \%$. Проте значну різноманітність грунтової схожості отримали з різних насаджень збору: 88 \% - відкритий простір, групове зростання, плоди великі; 66,5 \% - лісовий масив, середні плоди; 46,8 \% - лісовий масив, дерева пригнічені, плоди дрібні. У разі висівання плодами схожість низька - 24-36 \%. Плоди дуже часто піддаються впливу різних збудників мікозів: пліснявіння та гнилей, їх добувають птахи і тварини, тому частково чи повністю вони знищуються в посівах. Найсприятливіші терміни висіву в цьому регіоні це 15-20 вересня. На посів весною значно впливає весняна посуха, грунтова схожість знижується і становить 12-22 \%. Осінній посів дає змогу отримати садивний матеріал у більшій кількості, що сприятиме розширенню площ насаджень за участю береки лікарської.

Сьогодні дедалі більшої популярності набувають сучасні біотехнологічні підходи, які швидко й ефективно допомагають вирішувати складні завдання, що виникають перед лісівниками. Одним із таких методів є мікроклональне розмноження рослин. На території ДП "Чечельницьке ЛГ" берека трапляється у 84 кварталах (1244 га), яка здебільшого, має середні або дрібні плоди i не кожного року дерева плодоносять. Впровадження мікроклонального розмноження дає можливість у стислі терміни одержати масовий, генетично однорідний садивний матеріал з високими спадковими властивостями продуктивності та стійкості до збудників хвороб; виконувати роботу упродовж всього року; зекономити виробничі площі та використовувати передові індустріальні технології. 
Безумовно, цей метод $€$ технологічно складнішим, ніж польові умови, потребує відповідного обладнання і реактивів. Однак часом він є майже єдиним способом зберегти види, представлені малою кількістю екземплярів, або унікальні генотипи. Збереження генофонду одне 3 найважливіших завдань у справі збереження природи, якому приділяють значну увагу в усьому світі. За своєю суттю мікроклональне розмноження аналогічне вегетативному типу розмноження рослин з тією тільки різницею, що воно відбувається у пробірці в умовах in vitro. 3 клітин ізольованих тканин внаслідок можна отримати багато нових рослин (Kalinin, Kushnir \& Sarnatckaia, 1992).

Оскільки перебіг процесів морфогенезу у береки лікарської вивчено недостатньо, науковим відділом НПП "Кармелюкове Поділля" спільно 3 кафедрою лісового господарства Уманського національного університету садівництва (УНУС) проведено наукове дослідження щодо розроблення методики мікроклонального розмноження береки лікарської (лабораторія генетичних досліджень УНУС). Застосовано рекомендації Р. Г. Бутенко (Butenko, 1999) та М. Д. Мельничук (Melnychuk, Novak \& Kunakh, 2003).

Для введення в культуру in vitro використали живці, які нарізали $з$ дерев береки лікарської, що залишені на суцільних вирубках квартали 31/1 ${ }^{1}$, 95/4. Вибрані береки плодоносять щорічно, не пригнічені, ознак всихання, механічних пошкоджень, шкідників, захворювань не виявлено, середня вага плодів 2,58 г. 3 одного 30-річного дерева зібрали 12,5 кг плодів. Для порівняння встановили, що в дубово-ясеневих насадженнях плоди найдрібніші, середня вага плоду - 0,98 г, рясність плодоношення низька (менше 3 кг із 40-річного дерева); в дубово-грабових насадженнях середня вага плоду1,33 г, рясність середня (6-8 кг із 30-40-річних дерев). Це дані у високоврожайний 2018 р., а в береки лікарської переважають неврожайні роки.

Для введення в культуру in vitro були верхівкові бруньки, нарізали $з$ однорічних пагонів маточних рослин. На етапі стерилізації труднощі пов'язані з особливостями рослинного матеріалу, оскільки однорічні пагони береки лікарської, порівняно з іншими представниками роду Горобинних, мають твердішу кору і фаза здерев'яніння у них настає раніше від інших видів цього роду. Під час стерилізації утруднюється глибоке проникнення стерилізатора у тканини експланта, де містяться епіфітні грибки та бактерії. Найкращий результат отримали під час стерилізації $0,1 \% \mathrm{HgCl}_{2}, 1 \% \mathrm{Ag}$ $\mathrm{NO}_{3}$, експозиція 5 хв. Для культивування закладено 200 бруньок. Після культивування насіння отримали негативний результат навіть після холодової стратифікації та оброблення розчином гібереліну, які не вивели насіння із стану спокою.

Культивування біоматеріалу береки лікарської здійснювали на модифікованих середовищах МС (Murashige \& Skoog, 1962) під час внесення до його складу різних концентрацій регуляторів росту. Експланти культивували у культуральній кімнаті за температури $25^{\circ} \mathrm{C}$, фотоперіодом 16 год, освітленістю 3000-5000 лк та відносною вологістю повітря $70 \%$. Зі живців, які взяті 7 травня, отримали перші результати для пересаджування 21-30 червня, у цей період було введено 60 \% мікроживців. Підібрані оптимальні концентрації аукси- нів у складі живильного середовища, за яких відбувалися процеси ризогенезу. Кожного місяця новоутворені мікропагони відділяли від первинного експланта і пересаджували на свіже живильне середовище, до якого додавали фітогормони цитокінінового та ауксинового типу дій. Після додавання до живильного середовища БАП (бензиламінопурин) у концентрації 1 мг/л отримали значне зростання показника пагоноутворення. Пагони розвивались швидше і досягли 3,5 см. Після сумісного додавання до живильного середовища БАП1 мг/л та ІМК (індолілмасляну кислоту) - 0,3 мг/л відзначено, що коефіцієнт розмноження підвищився до 4,8, збільшилась висота пагонів та приріст листкової маси. Пагони були заввишки до 4,5 см та мали 5-6 добре сформованих листків, вони можуть бути матеріалом для подальших досліджень 3 масового розмноження та збереження цього виду на модифікованих живильних середовищах у стерильній культурі. Відпрацьований нами спосіб мікроклонального розмноження дає змогу декілька разів повторювати цикл мультиплікації, який містить:

- отримання нових експлантатів для мікроклонування;

- вкорінення мікроживців;

- повернення у цикл мікроклонального розмноження;

- адаптація до септичних умов і висаджування у відкритий грунт.

Отриманий матеріал реінтродукції in situ можна використовувати для вегетативного розмноження з метою поширення великоплідних особин, а також введення у промислову культуру й одержання цінної сировини для харчової промисловості та медицини. Перевагами цього методу, порівняно 3 традиційними, є: значно вищі коефіцієнти розмноження (можна отримати до 100.0001.000.000 меріклонів на рік); оздоровлення рослин від грибних і бактеріальних патогенів, вірусів; можливість розмноження і прискорення поширення рослин, розмноження яких утруднено звичайними способами. Хоча метод мікроклонального розмноження рослин є досить трудомістким і витратним, але на його основі можна створювати економічно рентабельні технології (Kalinin, Kushnir \& Sarnatckaia, 1992).

Висновки. За результатами дослідження встановлено, що природне насіннєве розмноження береки лікарської має незадовільну категорію, залежить від інтенсивності плодоношення, місць зростання, кількості вологи в осінній та весняний періоди.

Встановлено, що берека лікарська досить успішно може поновлюватися під час введення в культури дуба звичайного як супутня порода. Вирощування сіянців краще під час осінніх висівів у другій декаді вересня, рівень їх грунтової схожості є в межах 67,1 \%. Для весняного посіву насіння стратифікують протягом 90120 днів. Берека лікарська здатна утворювати пенькову поросль, але цей спосіб не використовують, рубати береку заборонено.

Впровадження перспективної технології мікроклонального розмноження виду дасть змогу отримати генетично ідентичні рослини з високими спадковими властивостями продуктивності та стійкості до збудників хвороби; скоротити і підвищити ефективність селекційного процесу. Збереження біорізноманіття - одне 3 найважливіших завдань у справі збереження природи. 


\section{Перелік використаних джерел}

Bondar, A. O., \& Hordiienko, M. I. (2006). Formuvannia lisovykh nasadzhen u dibrovakh Podillia. Kyiv: Urozhai, 336 p. [In Ukrainian].

Butenko, R. G. (1999). Biologiia kletok vysshikh rastenii in vitro i biotekhnologii na ikh osnove. Moscow: FBK-PRESS, 160 p. [In Russian].

Didukh, Ya. P. (Ed.). (2009). Roslynnyi svit: Chervona knyha Ukrainy. Kiev: Hlobalkonsaltynh, 912 p. [In Ukrainian].

Gorshenin, N. M., \& Shvidenko, A. I. (1977). Lesovodstvo. Lviv, 304 p. [In Russian].

Hordiienko, M. I., Koretskyi, H. S., \& Maurer, V. M. (1995). Lisovi kultury. Kiev: Silhosposvita, 328 p. [In Ukrainian].

Kalinin, F. L., Kushnir, G. P., \& Sarnatckaia, V. V. (1992). Tekhnologiia mikroklonalnogo razmnozheniia rastenii. Kiev: Scientific thought, 232 p. [In Russian].

Kushnir, H. P., \& Sarnatska, V. V. (2005). Mikroklonalne rozmnozhennia roslyn. Teoriia i praktyka. Kiev: Scientific thought, 243 p. [In Ukrainian].

Litopys. (2018). Litopys pryrody NPP "Karmeliukove Podillia". Chechelnyk, 5, 256. [In Ukrainian].

Melnychuk, M. D., Novak, T. V., \& Kunakh, V. A. (2003). Biotekhnolohiia roslyn. Kiev: PolihrafKonsaldynh, 520 p. [In Ukrainian].

Piatnitckii, S. S. (1994). Lesovozobnovlenie v usloviiakh Levoberezhnoi Lesostepi. Lesorazvedenie i vozobnovlenie: nauch. trudy, 45, 3-23. Kiev. [In Russian].

Pohrebniak, P. S. (1993). Lisova ekolohiia i typolohiia lisiv. Kiev: Scientific thought, 495 p. [In Ukrainian].
Shpak, N. P. (2016). Doslidzhennia pryrodnoho vidnovlennia Sorbus torminalis $\mathrm{v}$ lisovykh nasadzhenniakh NPP "Karmeliukove Podillia". Ridkisni roslyny i hryby Ukrainy ta prylehlykh terytorii: realizatsiia pryrodookhoronnykh stratehii: Proceedings of the IV International Conference, Kiev, May 16-20, 2016. Kiev: A. V. PALYVODA, 222 p. [In Ukrainian].

Shpak, N. P. (2018). Fruiting and natural restoration of Sorbus Torminalis (L.) Crantz under the oak stands canopy in the South-Podilsky forest-steppe of Ukraine. Scientific Bulletin of UNFU, 28(10), 5356. https://doi.org/10.15421/40281011

Shpak, N. P. (2019). Monitoring of natural renewal of species Sorbus Torminalis (L.) Crantz the conditions south of Podolsk Forest-Steppe of Ukraine. Scientific Bulletin of UNFU, 29(5), 27-30. https://doi.org/10.15421/40290505

Shpak, N. P., Shlapak, V. P., \& Leontiak, H. P. (2017). Some peculiarities of cultivation of common oak stands involving bereka medicinal in southern podillya. Scientific Bulletin of UNFU, 27(3), 7174. https://doi.org/10.15421/40270315

Termena, B. K., \& Budzhak, V. V. (1997). Reproduktyvnyi potentsial Sorbus torminalis (L.) Crantz. v umovakh Pivnichnoi Bukovyny. Problemy eksperymentalnoi botaniky ta ekolohii roslyn: collection of scientific labours, 1, 150-153. Kiev: Scientific thought. [In Ukrainian].

Tsymbal, O. M. (2011). Sorbus torminalis (L.) Crantz. u Natsionalnomu dendrolohichnomu parku "Sofiivka" NAN Ukrainy. Vidnovlennia porushenykh pryrodnykh ekosystem: Proceedings of the IV Scientific Conference. Donetsk. (pp. 388-389). [In Ukrainian].

\section{THE USE OF DIFFERENT METHODS OF REPRODUCTION OF SORBUS TORMINALIS (L.) CRANTZ FOR RENEWAL IN FRESH OAK FORESTS OF SOUTH PODILLYA FOREST-STEPPE OF UKRAINE}

Reforestation with the participation of valuable species of wood at the current stage of development of society is an urgent task for forestry. Sorbus torminalis (L.) Crantz is a native species listed in the Red Book of Ukraine (2009). It is the natural satellite of the forest cenosis of the South Podillya Forest-Steppe of Ukraine, which renewal had been studied for five years in wood stands of all age categories and on $\log$ cabins where reproductive individuals of the species were left. To study the quantitative and qualitative indicators of the renewal of Sorbus torminalis, 60 temporary and 11 permanent trial plots were laid. Natural seed reproduction of Sorbus torminalis was found in fresh oak forests of the South Podillya. The seeds remain viable for 1-2 years. In the natural oakhornbeam planting fruiting comes in 20-year-old age, the mass fruiting after one time per 5 was observed. Seed reproduction is used to obtain seedlings for introduction of Sorbus torminalis to the cultures of oak ordinary. The cultivation of seedlings is better for autumn sowing, provided the technology is respected. Successful autumn seedling should be carried out in the second decade of September. Such seedlings give friendly stairs and level of their soil similarity is within $78 \%$, which is quite a successful result. Vegetative overgrowth reproduction assists its renewal at mechanical damages. The problem of species reproduction and recovery can be solved with the use of modern biotechnology. One the method is microclonal reproduction. This method allows obtaining mass, genetically homogeneous planting material with high hereditary properties of productivity and resistance to pathogens in a short time. Apical buds cut from annual shoots of uterine plants served for in vitro culture. Selection of sterilizers was carried out, and appropriate concentrations of nutrient medium and exposure were also determined. The introduction of different methods of reproduction of Sorbus torminalis will contribute to the restoration of plantations with its participation, as well as the expansion of the range of the endangered species.

Keywords: Sorbus torminalis; sexual reproduction; vegetative reproduction; microclonal reproduction. 